\title{
Plasmacytoid dendritic cell interferon- $a$ production to R-848 stimulation is decreased in male infants
}

Jennifer P Wang ${ }^{*}$, Lei Zhang, Rachel F Madera, Marcia Woda and Daniel H Libraty

\begin{abstract}
Background: Sex differences in response to microbial infections, especially viral ones, may be associated with Toll-like receptor (TLR)-mediated responses by plasmacytoid dendritic cells (pDCs).

Results: In this study, we identified sex differences in human infant pDC interferon-a production following challenge with the TLR7/8 agonist R-848. Male $\mathrm{pDC}$ responses were significantly lower than those of females during early infancy. This difference may be attributed to the androgen surge experienced by males during the early infancy period. Pretreatment of human pDCs with dihydrotestosterone produced a significant reduction in interferon-a production following R-848 challenge.
\end{abstract}

Conclusions: Androgen-mediated regulation of pDC TLR7-driven innate immune responses may contribute to the observed sex differences in response to infections during early infancy.

Keywords: pDC, IFN-a, TNF-a, Infant, TLR7

\section{Background}

Plasmacytoid DCs (pDCs) are highly specialized cells that produce large amounts of interferon- $\alpha$ (IFN- $\alpha$ ) in response to a wide range of viruses and other microbial stimuli [1,2]. Infant and adult human pDCs express high levels of Toll-like receptors (TLRs) 7 and 9, but not TLR8 $[3,4]$. Human TLRs 7 and 8 are members of the endosomal TLR9 subfamily that sense RNA moieties intracellularly and signal through the adaptor MyD88 [5]. The imidazoquinolone and guanosine-like compound, resiquimod (R-848), stimulates human TLRs 7/8 [6,7].

Sex differences in adult pDC IFN- $\alpha$ production have been previously described, with production being higher in females than males $[8,9]$. However, the reported effects of female sex hormones on TLR7-mediated pDC IFN- $\alpha$ production have been varied [8-10]. The effects of male sex hormones have not been previously determined. Within the first six months of life, infants experience a "mini-puberty". During this time period, circulating levels of sex hormones approach the levels

\footnotetext{
* Correspondence: Jennifer.wang@umassmed.edu

Division of Infectious Disease and Immunology, Department of Medicine, University of Massachusetts Medical School, 364 Plantation, Worcester, MA 01605, USA
}

(c) 2012 Wang et al.; licensee BioMed Central Ltd. This is an Open Access article distributed under the terms of the Creative Commons Attribution License (http://creativecommons.org/licenses/by/2.0), which permits unrestricted use, distribution, and reproduction in any medium, provided the original work is properly cited.
As part of a prospective study of dengue virus infections during infancy in San Pablo, Philippines, we collected peripheral blood mononuclear cells (PBMC) from healthy infants at approximately two months of age. We measured $\mathrm{pDC}$ IFN- $\alpha$ and tumor necrosis factor- $\alpha$ (TNF- $\alpha$ ) production to $1 \mu \mathrm{M}$ R-848 stimulation by intracellular cytokine staining (ICS) in healthy infant PBMC from 47 randomly selected donors (ages $=2.1$ [1.6-3.8] months). Figure 1a shows the gating strategy for the flow seen during puberty [11]. We found that during the "mini-puberty" period female infant pDCs also have higher $\mathrm{pDC}$ IFN- $\alpha$ production than male infants in response to $1 \mu \mathrm{M}$ R-848 stimulation. Androgen signaling downregulated R-848 stimulated $\mathrm{pDC}$ IFN- $\alpha$ production. This sex effect on pDC IFN- $\alpha$ production may play a role in the female survival benefit seen during early incost of higher rates of systemic lupus erythematosus (SLE) and autoimmune diseases later in adult females compared to adult males [12,13]. Here we describe a novel effect of male sex hormones on TLR7-mediated pDC IFN- $\alpha$ production.

\section{Results and discussion}


(a)

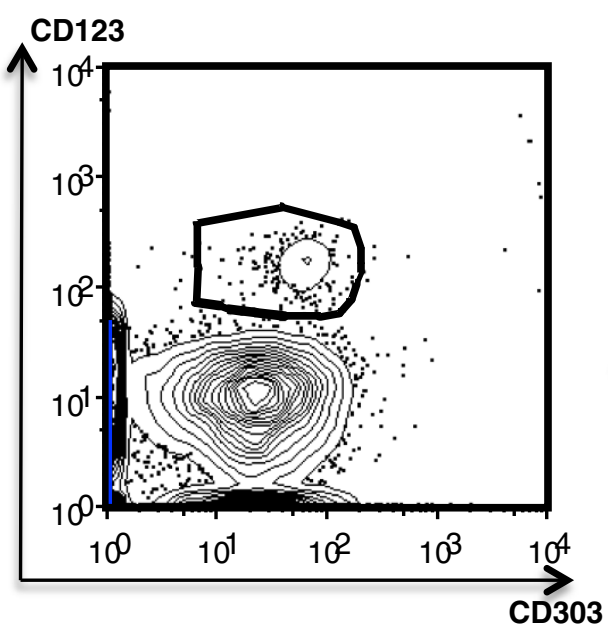

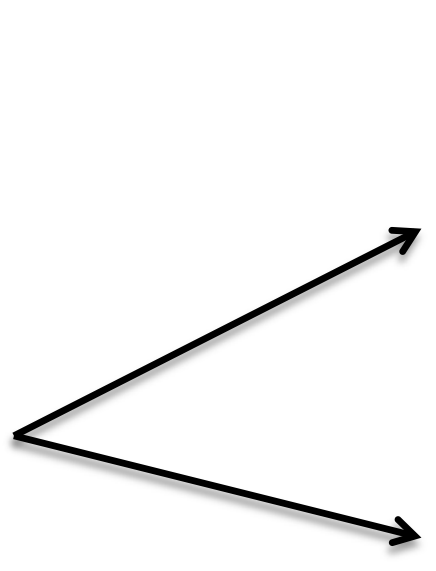

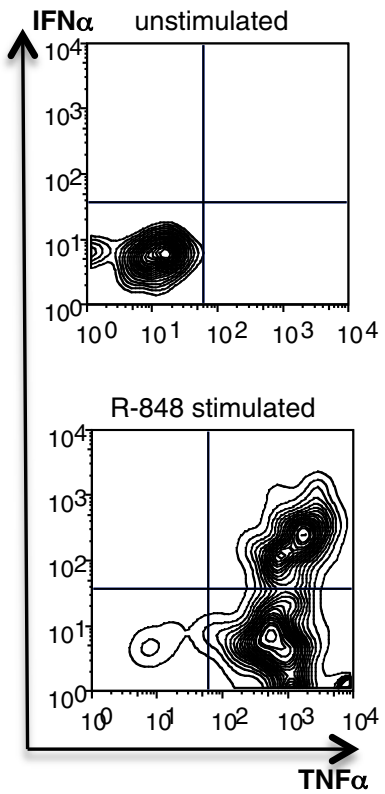

(b)

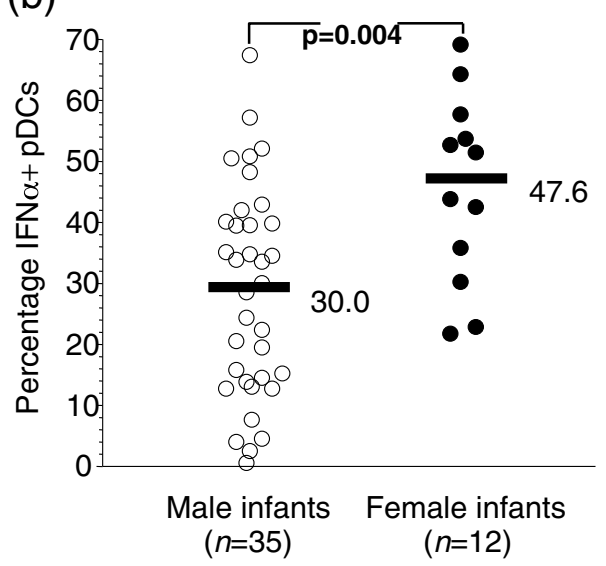

(c)

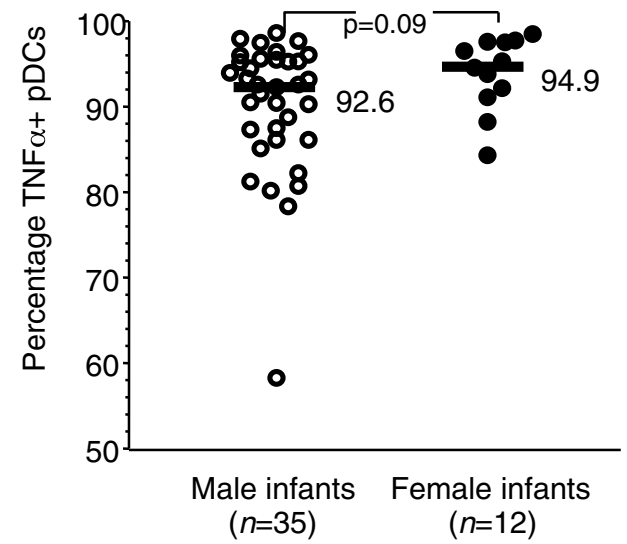

Figure 1 Intracellular cytokine staining for IFN- $\boldsymbol{a}$ and TNF- $\boldsymbol{a}$ in pDCs upon $1 \boldsymbol{\mu M}$ R-848 stimulation. a pDCs were gated as CD123 $3^{+} \mathrm{CD} 303^{+}$ cells in infant PBMC (left column) after selection for live (Live/Dead Aqua -), single, and large mononuclear cells. All IFN-a producing pDCs upon $1 \mu \mathrm{M}$ R-848 stimulation also produced TNF-a (right column). One representative example of the gating strategy in infant PBMC is shown. $\mathbf{b}$ The percentage of IFN- $a+p D C s, \mathbf{c}$ but not TNF- $a+p D C s$, is higher in female infants compared to male infants upon $1 \mu M$ R-848 stimulation. Infant age $=2.1$ [1.6-3.8] months (median [95 \% CI]). Unstimulated background is subtracted from the values. Bars = median values. Comparisons were performed using the non-parametric Mann Whitney $\mathrm{U}$ test. P-values $<0.05$ were considered significant.

cytometry. pDCs were $2.2[0.8-6.2] \%$ of live PBMC in our early infancy samples. We found that the percentage of IFN- $\alpha+$ pDCs (Figure 1b), but not TNF- $\alpha+$ pDCs (Figure 1c), was significantly higher in female infants compared to male infants following $1 \mu \mathrm{M}$ R-848 stimulation. There were no significant differences in age or World Health Organization (WHO) anthropometric measures between the sexes (weight-for-age, length-forage, weight-for-length, or body mass index-for-age $\mathrm{z}$ scores). PBMC viability was measured by trypan blue exclusion in the cell cultures and was similar between the two sexes (data not shown). Higher R-848 and TLR7- mediated pDC IFN- $\alpha$ production has been previously reported in adult females compared to adult males [8,9]. To the best of our knowledge, this is the first time a similar phenomenon has been reported during early infancy. TLR7 expression has not been found to be different between the sexes [8]. In one report, 17- $\beta$-estradiol was reported to augment TLR9-mediated pDC IFN- $\alpha$ production [14]; but in another report, 17- $\beta$-estradiol did not affect TLR7-mediated PDC IFN- $\alpha$ production [8]. The reported effects of progesterone on TLRmediated pDC IFN- $\alpha$ production have also been conflicting. Meier et al. demonstrated that plasma 
progesterone levels significantly correlated with $\mathrm{pDC}$ IFN- $\alpha$ production in response to stimulation with an HIV-1-derived TLR7/8 ligand [9]. By contrast, Hughes et al. found that progesterone inhibited CpG-mediated and vesicular stomatitis virus-induced IFN- $\alpha$ production by pDCs [10].

During the "mini-puberty" stage [11], male infants have markedly higher circulating testosterone and dihydrotestosterone (DHT) levels compared to female infants [15]. We therefore hypothesized that androgen signaling would decrease $\mathrm{pDC}$ IFN- $\alpha$ production in response to R-848 stimulation. DHT is a more potent androgen than testosterone [16]. Pretreatment of female adult pDCs with DHT decreased R-848-stimulated IFN$\alpha$ production, but not TNF- $\alpha$ production, in a dose dependent manner (Figure 2). A similar finding was seen for CpG-mediated TLR9 stimulation in the pDCs (data not shown). The downregulation of TLR7 and TLR9 stimulated $\mathrm{pDC}$ IFN- $\alpha$ production contrasts with the reported positive associations between androgens and serum inflammatory markers [17]. $\mathrm{pDC}$ IFN- $\alpha$ production is dependent on interferon regulatory factor 7 (IRF7) [18]. The IRF7 promoter contains androgen responsive elements and higher levels of IRF7 have been seen in the lungs of female Norway rats compared to males [19]. We postulate that the lower R-848 stimulated $\mathrm{pDC}$ IFN- $\alpha$ production in male infants is at least partly due to androgen effects on IRF7 levels within the first six months of life. Future studies are planned to examine the effect of androgens on pDC IRF7 levels.

Female infants enjoy a survival benefit compared to male infants in the first six months of life. In particular, Staphylococcus aureus infections [20] and respiratory viral infections such as respiratory syncytial virus (RSV) [21] predominate in males during early infancy. Staphylococcus aureus and several airborne and respiratory RNA viruses (including RSV) can modulate TLR7mediated $\mathrm{pDC}$ IFN- $\alpha$ production during their pathogenesis [22-24]. Higher pDC IFN- $\alpha$ production in females during early infancy may contribute to their survival benefit. Later in life, this sex effect may contribute to a higher incidence of SLE and autoimmune diseases in females [12,13].

\section{Conclusions}

We found that R-848-stimulated $\mathrm{pDC}$ IFN- $\alpha$ production, but not $\mathrm{pDC}$ TNF- $\alpha$ production, was higher in girls compared to boys during early infancy. Androgen signaling downregulated R-848-stimulated $\mathrm{pDC}$ IFN- $\alpha$ production, but not pDC TNF- $\alpha$ production, in a dose dependent fashion. We postulate that androgen effects on pDCs play a role during the "mini-puberty" of early infancy in the sex differences of R-848-stimulated pDC IFN- $\alpha$ production.

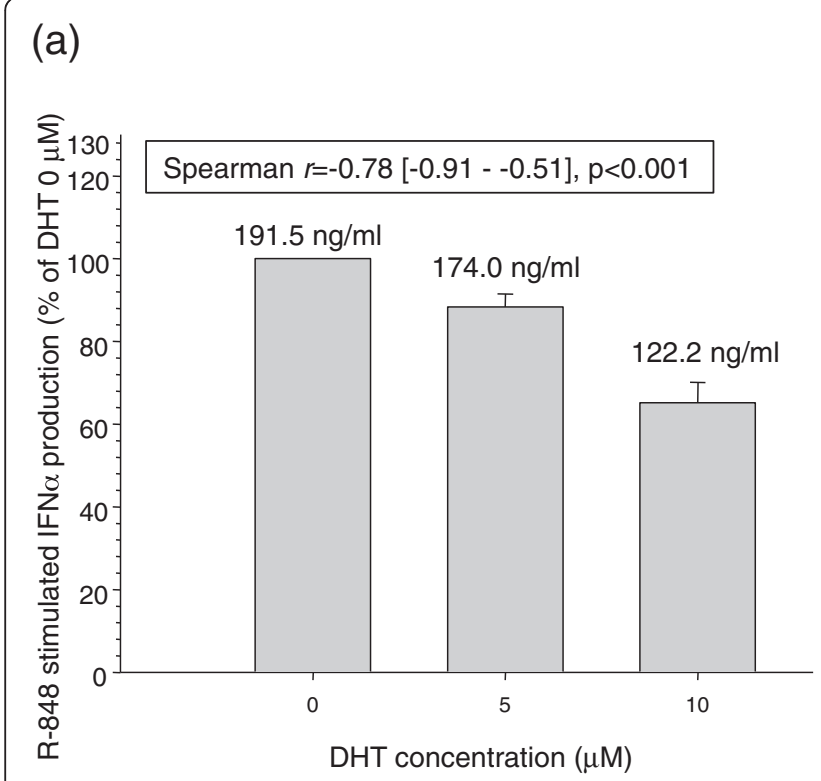

(b)

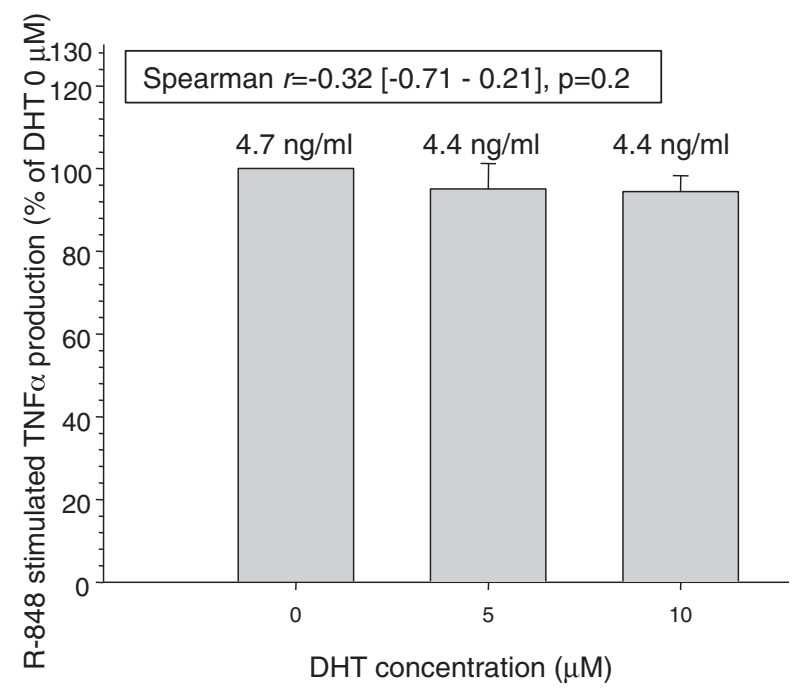

Figure 2 The androgen dihydrotestosterone (DHT) decreases pDC R-848-stimulated IFN-a production, but not TNF-a, in a dosedependent manner. IFN- $\alpha$ and TNF- $a$ production were measured by ELISA in cell-free culture supernatants from $5 \times 10^{4}$ purified healthy adult female pDCs/well. pDC viability was measured by trypan blue exclusion and was similar in all groups (data not shown). a pDC IFN-a production due to R-848 $1 \mu \mathrm{M}$ stimulation; $n=5$ independent experiments (\% of pDC IFN-a production at DHT $0 \mu \mathrm{M}$ ). $\mathbf{b}$ pDC TNF-a production due to R-848 $1 \mu \mathrm{M}$ stimulation; $n=4$ independent experiments (\% of pDC TNF-a production at DHT $0 \mu \mathrm{M}$ ). Bar values and error bars are mean \pm S.E.; Spearman $r$ values and $[95 \%$ confidence intervals] are shown. Numbers above bars are mean cytokine supernatant levels (ng/ml). P-values $<0.05$ were considered significant. 


\section{Methods}

\section{Infant clinical study}

The infant clinical study was approved by the institutional review boards of the Research Institute for Tropical Medicine, Philippines, and the University of Massachusetts Medical School (UMMS). Mothers and their healthy infants were recruited and enrolled after providing written informed consent. Study enrollment began in October 2006 in San Pablo, Philippines. Blood samples were collected from healthy infants and their mothers when the infant was between 6-18 weeks old. Normalized child growth indicators were determined using WHO child growth standards [25]. PBMC were isolated by Ficoll-Hypaque density centrifugation from infant blood samples and cryopreserved.

\section{Antibodies and fluorophores}

The following monoclonal antibodies (mAbs) and fluorophores were used: mouse mAb anti-human CD123 eFluor NC650 (eBioscience, San Diego, CA), anti-human CD303 APC (Miltenyi Biotec, Auburn, CA), anti-human tumor necrosis factor- $\alpha$ (TNF- $\alpha$ ) PerCPCy5.5 (Biolegend, San Diego, CA), and anti-human IFN- $\alpha$ FITC (PBL Interferon Source, Piscataway, NJ).

\section{Intracellular cytokine staining (ICS)}

PBMC were resuspended in RPMI 1640 (Invitrogen Life Technologies, Grand Island, NY), 10 \% FCS (HyClone, Logan, UT), $10 \mathrm{ng} / \mathrm{ml} \mathrm{rIL}-3$ (R\&D Systems, Minneapolis, $\mathrm{MN}$ ), and $20 \mu \mathrm{g} / \mathrm{ml}$ DNase (Sigma-Aldrich, St. Louis, $\mathrm{MO}) .1 .5 \times 10^{6} \mathrm{PBMC}$ were placed in polypropylene tubes with $1 \mu \mathrm{M}$ R-848 (Invivogen, San Diego, CA $0.5 \mu \mathrm{g} / \mathrm{ml}$ brefeldin A (BD Pharmingen, San Diego, CA), and incubated for $16 \mathrm{~h}$ in a $37{ }^{\circ} \mathrm{C} / 5 \% \mathrm{CO}_{2}$ incubator. The PBMC were then stained with Live/Dead Aqua (Invitrogen Life Technologies, Grand Island, NY), fixed and permeabilized (Invitrogen Life Technologies), and stained for pDC markers (CD123 and CD303) and cytokine production (IFN- $\alpha$ and TNF- $\alpha$ ). Flow cytometry data was acquired on a FACSAria (BD Biosciences, San Diego, CA).

\section{Cell culture and ELISAs}

Human pDCs were isolated from the blood of healthy adult donors under a protocol approved by the UMMS Institutional Review Board. PBMC were isolated using Ficoll-Hypaque density centrifugation, and pDCs were positively selected from the PBMC using magnetic beads (Miltenyi Biotec, Auburn, CA). $5 \times 10^{4}$ pDCs were cultured in 96-well plates in $200 \mu \mathrm{l}$ RPMI 1640, $10 \%$ FCS, and $10 \mathrm{ng} / \mathrm{ml} \mathrm{rIL-3.} 1 \mu \mathrm{M}$ R-848 or $7.5 \mu \mathrm{g} / \mathrm{ml} \mathrm{CpG} 2336$ (Coley Pharmaceuticals, Wellesley, MA) was added to pDC cultures overnight in a $37{ }^{\circ} \mathrm{C} / 5 \% \mathrm{CO}_{2}$ incubator; cell-free culture supernatants were collected for ELISAs at $18-24 \mathrm{~h}$. IFN- $\alpha$ and TNF- $\alpha$ ELISAs (R\&D Systems) were performed per the manufacturer's instructions. All samples were assayed in duplicate. In some experiments, pDCs were pretreated for $1 \mathrm{~h}$ with dihydrotestosterone (DHT, Sigma-Aldrich) at the indicated concentrations.

\section{Statistical analysis}

The SPSS software package (version 19.0) was used for statistical analyses. Comparisons between two groups were performed using a two-tailed Mann-Whitney U test. Spearman's correlation was also determined. $\mathrm{P}<0.05$ was considered significant. Values are presented as the median [95\% confidence interval (CI)].

\section{Abbreviations}

Cl: Confidence interval; DHT: Dihydrotestosterone; ICS: Intracellular cytokine staining; IFN-a: Interferon-a; IRF7: Interferon regulatory factor 7; mAbs: Monoclonal antibodies; PBMC: Peripheral blood mononuclear cells; pDC: Plasmacytoid dendritic cell; RSV: Respiratory syncytial virus:

SLE: Systemic lupus erythematosus; TLR: Toll-like receptor; TNF-a: Tumor necrosis factor-a; UMMS: University of Massachusetts Medical School; WHO: World Health Organization.

\section{Competing interests}

There are no competing interests.

\section{Acknowledgments}

The authors would like to acknowledge Rosario Z. Capeding, Luz Acosta, Linda Dexter-Fraser, and Ronald Banez for assistance with the infant clinical study and PBMC collection.

This work was supported by NIH/NIAID grants R01Al092105 (to J.P.W.) and U01Al065654 and R01Al091820 (to D.H.L.).

\section{Authors' contributions}

JPW- analyzed and interpreted data, wrote the manuscript. LZ- performed research, collected data. RFM- analyzed and interpreted data, wrote the manuscript. MW- performed research, collected data. DHL- designed research, performed statistical analysis, analyzed and interpreted data, wrote the manuscript. All authors read and approved the final manuscript.

Received: 12 April 2012 Accepted: 6 July 2012

Published: 6 July 2012

\section{References}

1. McKenna K, Beignon AS, Bhardwaj N: Plasmacytoid dendritic cells: linking innate and adaptive immunity. J Virol 2005, 79:17-27.

2. Fitzgerald-Bocarsly P: Natural interferon-alpha producing cells: the plasmacytoid dendritic cells. Biotechniques 2002, 22(16-20):24-29.

3. Corbett NP, Blimkie D, Ho KC, Cai B, Sutherland DP, Kallos A, Crabtree J, Rein-Weston A, Lavoie PM, Turvey SE, et al: Ontogeny of Toll-like receptor mediated cytokine responses of human blood mononuclear cells. PLOS One 2010, 5:e15041.

4. Lan T, Putta MR, Wang D, Dai M, Yu D, Kandimalla ER, Agrawal S: Synthetic oligoribonucleotides-containing secondary structures act as agonists of Toll-like receptors 7 and 8 . Biochem Biophys Res Commun 2009, 386:443-448.

5. Wagner $\mathrm{H}$ : The immunobiology of the TLR9 subfamily. Trends Immunol 2004, 25:381-386.

6. Heil F, Ahmad-Nejad P, Hemmi H, Hochrein H, Ampenberger F, Gellert T, Dietrich H, Lipford G, Takeda K, Akira S, et al: The Toll-like receptor 7 (TLR7)-specific stimulus loxoribine uncovers a strong relationship within the TLR7, 8 and 9 subfamily. Eur J Immunol 2003, 33:2987-2997.

7. Jurk M, Heil F, Vollmer J, Schetter C, Krieg AM, Wagner H, Lipford G, Bauer S: Human TLR7 or TLR8 independently confer responsiveness to the antiviral compound R-848. Nat Immunol 2002, 3:499. 
8. Berghofer B, Frommer T, Haley G, Fink L, Bein G, Hackstein H: TLR7 ligands induce higher IFN-alpha production in females. J Immunol 2006, 177:2088-2096.

9. Meier A, Chang JJ, Chan ES, Pollard RB, Sidhu HK, Kulkarni S, Wen TF, Lindsay RJ, Orellana L, Mildvan D, et al: Sex differences in the Toll-like receptor-mediated response of plasmacytoid dendritic cells to HIV-1. Nat Med 2009, 15:955-959.

10. Hughes GC, Thomas S, Li C, Kaja MK, Clark EA: Cutting edge: progesterone regulates IFN-alpha production by plasmacytoid dendritic cells. $\mathrm{J}$ Immunol 2008, 180:2029-2033.

11. Quigley CA: Editorial: the postnatal gonadotropin and sex steroid surge-insights from the androgen insensitivity syndrome. J Clin Endocrinol Metab 2002, 87:24-28.

12. Lockshin MD: Sex differences in autoimmune disease. Lupus 2006, 15:753-756.

13. Barrat FJ, Meeker T, Gregorio J, Chan JH, Uematsu S, Akira S, Chang B, Duramad O, Coffman RL: Nucleic acids of mammalian origin can act as endogenous ligands for Toll-like receptors and may promote systemic lupus erythematosus. J Exp Med 2005, 202:1131-1139.

14. Li X, Xu Y, Ma L, Sun L, Fu G, Hou Y: 17beta-estradiol enhances the response of plasmacytoid dendritic cell to CpG. PLoS One 2009, 4:e8412.

15. Pang S, Levine LS, Chow D, Sagiani F, Saenger P, New Ml: Dihydrotestosterone and its relationship to testosterone in infancy and childhood. J Clin Endocrinol Metab 1979, 48:821-826.

16. Grino PB, Griffin JE, Wilson JD: Testosterone at high concentrations interacts with the human androgen receptor similarly to dihydrotestosterone. Endocrinology 1990, 126:1165-1172.

17. Meyer TE, Chu LW, Li Q, Yu K, Rosenberg PS, Menashe I, Chokkalingam AP, Quraishi SM, Huang WY, Weiss JM, et al: The association between inflammation-related genes and serum androgen levels in men: the prostate, lung, colorectal, and ovarian study. Prostate 2012, 72:65-71.

18. Tailor P, Tamura T, Ozato K: IRF family proteins and type I interferon induction in dendritic cells. Cell Res 2006, 16:134-140.

19. Hannah MF, Bajic VB, Klein SL: Sex differences in the recognition of and innate antiviral responses to Seoul virus in Norway rats. Brain Behav Immun 2008, 22:503-516.

20. Thompson DJ, Gezon HM, Hatch TF, Rycheck RR, Rogers KD: Sex distribution of Staphylococcus aureus colonization and disease in newborn infant. N Engl J Med 1963, 269:337-341.

21. Simoes EA: Environmental and demographic risk factors for respiratory syncytial virus lower respiratory tract disease. I Pediatr 2003, 143:S118-S126.

22. Parcina M, Wendt C, Goetz F, Zawatzky R, Zahringer U, Heeg K, Bekeredjian-Ding I: Staphylococcus aureus-induced plasmacytoid dendritic cell activation is based on an IgG-mediated memory response. J Immunol 2008, 181:3823-3833.

23. Schlender J, Hornung V, Finke S, Gunthner-Biller M, Marozin S, Brzozka K, Moghim S, Endres S, Hartmann G, Conzelmann KK: Inhibition of toll-like receptor 7- and 9-mediated alpha/beta interferon production in human plasmacytoid dendritic cells by respiratory syncytial virus and measles virus. J Virol 2005, 79:5507-5515.

24. Hornung V, Schlender J, Guenthner-Biller M, Rothenfusser S, Endres S, Conzelmann KK, Hartmann G: Replication-dependent potent IFN-alpha induction in human plasmacytoid dendritic cells by a single-stranded RNA virus. J Immunol 2004, 173:5935-5943.

25. WHO Multicentre Growth Reference Study Group: WHO Child Growth Standards: Length/height-for-age, weight-for-age, weight-for-length, weight-for-height and body mass index-for-age: Methods and development. Geneva: World Health Organization; 2006 (312 pages).

doi:10.1186/1471-2172-13-35

Cite this article as: Wang et al:: Plasmacytoid dendritic cell interferon- $a$ production to R-848 stimulation is decreased in male infants. BMC Immunology 2012 13:35.

\section{Submit your next manuscript to BioMed Central and take full advantage of:}

- Convenient online submission

- Thorough peer review

- No space constraints or color figure charges

- Immediate publication on acceptance

- Inclusion in PubMed, CAS, Scopus and Google Scholar

- Research which is freely available for redistribution

Submit your manuscript at www.biomedcentral.com/submit
Ciomed Central 